\section{Implementasi Sistem Manajemen K3 Pada Konstruksi Jalan Sebagai Upaya Pencegahan Kecelakaan Kerja}

\section{Qomariyatus Sholihah}

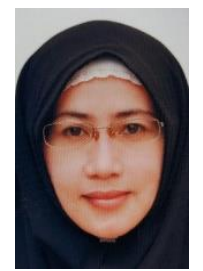

Penulis adalah staff pengajar Program Studi Program Profesi Insinyur Universitas Lambung Mangkurat. Bidang keahlian penulis adalah teknik industr khususnya sistem manajemen keselamatan dan kesehatan kerja. qoqom_kuncoro@yahoo.co.nz
Penulisan ini bertujuan untuk (1) Mengetahui pelaksanaan sistem manajemen kesehatan dan keselamatan kerja pada proyek Pembangunan Jalan Akses Menuju Pelabuhan Trisakti-Liang Anggang, dan (2) Mengetahui keadaan kelengkapan fasilitas yang berkaitan dengan pelaksanaan sistem kesehatan dan keselamatan kerja pada proyek. Setelah dilakukan analisis sistem kesehatan dan keselamatan kerja, didapatkan bahwa (1) Pelaksanaan sistem manajemen kesehatan dan keselamatan kerja pada sistem kesehatan dan keselamatan kerja dalam kondisi yang baik. Hal tersebut diwujudkan dalam bentuk kinerja penerapan penyelenggaraan kesehatan dan keselamatan kerja berdasarkan Peraturan Menteri PU No. 9 tahun 2008 dengan nilai 88,295\%, (2) Kelengkapan fasilitas yang berkaitan dengan pelaksanaan sistem kesehatan dan keselamatan kerja dikategorikan baik, yang ditunjukkan dari hasil Penilaian Kelengkapan Fasilitas keselamatan dan kesehatan kerja berdasarkan Peraturan Menteri PU No. 9 tahun 2008 dengan nilai $82,1 \%$.

Kata kunci: Sistem manajemen K3, konstruksi, jalan raya, kecelakaan, Jamsostek.

www.buletinppi.ulm.ac.id

\section{Pendahuluan}

Proyek konstruksi memiliki sifat yang khas, antara lain tempat kerjanya di ruang terbuka yang dipengaruhi cuaca, jangka waktu pekerjaan terbatas, menggunakan pekerja yang belum terlatih, menggunakan peralatan kerja yang membahayakan keselamatan dan kesehataan kerja dan pekerjaan yang banyak mengeluarkan tenaga. Berdasarkan sifat-sifat unik itu pula, maka sektor jasa kontruksi mempunyai resiko biaya kecelakaan fatal (Pangkey dkk, 2012).

Sebagai gambaran, data angka kecelakaan kerja dari PT. Jamsostek Tahun 2011 di Indonesia tercatat 96.314 kasus kecelakaan kerja, dimana terdapat 2.144 orang meninggal, 42 orang cacat total. Sebagian besar pekerja yang ditanyakan mengenai berbagai hal tentang $\mathrm{K} 3$, tidak mengetahui secara jelas mengenai $\mathrm{K} 3$ meskipun pernah mendengarnya. Hal ini berarti bahwa persoalan K3 bagi pekerja ditempatkan jauh di bawah persoalan seperti upah rendah serta hak-hak lainnya.

Untuk memperkecil risiko kecelakaan kerja pemerintah telah mengeluarkan suatu peraturan tentang keselamatan kerja khusus untuk sektor konstruksi yaitu peraturan Menteri Tenaga Kerja dan Transmigrasi no. PER 01/Men/1980 (Pangkey, 2012).

SMK3 merupakan bagian yang tidak terpisah dari sistem perlindungan tenaga kerja dan bagi pekerjaan jasa konstruksi dapat meminimalisasi dan menghindarkan diri dari risiko kerugian moral maupun material, kehilangan jam kerja, maupun keselamatan manusia dan lingkungan sekitarnya yang nantinya dapat menunjang peningkatan kinerja yang efektif dan efisien dalam proses pembangunan (Sholihah, 2012).
Peraturan mengenai keselamatan kerja untuk konstruksi tersebut dinilai memadai untuk kondisi minimal, hal yang sangat disayangkan adalah pada penerapan peraturan tersebut di lapangan. Rendahnya kesadaran masyarakat pada masalah keselamatan kerja dan rendahnya tingkat penegakan hukum oleh pemerintah, mengakibatkan penerapan peraturan keselamatan kerja yang masih jauh dari optimal, yang pada akhirnya menyebabkan masih tingginya angka kecelakaan kerja (Sholihah, 2013).

Pada proyek Pembangunan Jalan Akses Menuju Pelabuhan Trisakti-Liang Anggang, terdapat ketidaksesuaian antara pemahaman pengetahuan K3. Ada pekerja yang tidak sadar berperilaku tidak aman (unsafe action), ada pekerja yang bekerja dengan tidak aman meskipun sudah tahu bagaimana seharusnya bekerja secara aman, dan ada juga pekerja yang menyadari dirinya berkompeten, tetapi perlu pengarahan dan bimbingan. Untuk itu, perlu diketahui pengaruh pengetahuan K3 terhadap perilaku pekerja konstruksi dilihat dari beberapa aspek terkait K3 seperti definisi dan inisiasi, sistem manajemen, mekanisme alat pelindung diri, sarana dan prasarana, serta risiko K3 ().

Secara umum pengetahuan tentang $\mathrm{K} 3$ sangat luas, ada beberapa komponen $\mathrm{K} 3$ yang dipandang penting untuk dijadikan tolak ukur pemahaman K3. Komponen-kompenen tersebut adalah definisi dan inisiasi K3, Sistem Manajemen K3 (SMK3), Alat Pelindung Diri (APD), Sarana dan Prasarana K3, Risiko K3.

Definisi dan inisiasi bermanfaat untuk gambaran awal tentang K3 pada suatu proyek konstruksi yang erat kaitannya dengan pengenalan secara umum seperti misalnya definisi istilah-istilah, kepanjangan dari singkatan-singkatan, arti dan makna lambang K3, struktur 
Buletin Profesi Insinyur 1(1) (2018) 25-31

organisasi yang terlibat, pihak internal dan eksternal terkait fungsi pelaksanaan $\mathrm{K} 3$, dan sebagainya.

Proses SMK3 menggunakan pendekatan PDCA (Plan Do Check Action) yaitu mulai dari perencanaan, penerapan, pemeriksaan, dan tindakan perbaikan. Dengan demikian, SMK3 akan berjalan terus-menerus secara berkelanjutan selama aktivitas organisasi masih berlangsung.

Perlindungan keamanan dan keselamatan pekerja dalam suatu kegiatan konstruksi seharusnya dilakukan secara sungguh-sungguh melalui berbagai cara untuk mengurangi sumber bahaya dengan menggunakan alat pelindung diri (personal protective devices). Namun dalam realisasinya pemakaian APD masih sangat sulit, mengingat para pekerja akan menganggap bahwa alat ini akan mengganggu pekerjaan.

Komponen penting lainnya yaitu risiko K3, yang menggambarkan besarnya potensi bahaya pada pekerjaan konstruksi untuk dapat menimbulkan insiden atau cedera pada pekerja yang ditentukan oleh kemungkinan dan keparahan yang diakibatkannya, sehingga harus dikelola dan dihindarkan melalui manajemen K3 yang baik (Teja, 2015).

Penulisan ini bertujuan untuk : (1) Mengetahui pelaksanaan SMK3 pada proyek Pembangunan Jalan Akses Menuju Pelabuhan Trisakti-Liang Anggang, dan (2) Mengetahui keadaan kelengkapan fasilitas yang berkaitan dengan pelaksanaan sistem SMK3 pada proyek Pembangunan Jalan Akses Menuju Pelabuhan Trisakti-Liang Anggang.

\section{Metode dan Literatur}

Keselamatan dan Kesehatan Kerja

Keselamatan kerja adalah keselamatan yang berkaitan dengan mesin, pesawat, alat kerja, bahan dan proses pengolahannya, landasan tempat kerja dan lingkungannya serta cara-cara melakukan pekerjaan. (Ridley, 2004). Keselamatan dan kesehatan kerja (K3) difilosofikan sebagai suatu pemikiran dan upaya untuk menjamin keutuhan dan kesempurnaan baik jasmani maupun rohani tenaga kerja pada khususnya dan manusia pada umumnya, hasil karya dan budayanya menuju masyarakat makmur dan sejahtera. Sedangkan pengertian secara keilmuan adalah suatu ilmu pengetahuan dan penerapannya dalam usaha mencegah kemungkinan terjadinya kecelakaan dan penyakit akibat kerja. (Armanda, 2006).

\section{Kecelakaan Kerja}

Beberapa pengertian kecelakaan menurut Dale S. Beach, kecelakaan adalah suatu kejadiaan peristiwa yang tidak diharapkan yang merintangi atau mengganggu jalannya kegiatan biasa (Moekijat, 1999). Menurut Drs. Moekijat kecelakaan adalah apa saja yang tidak direncanakan atau yang tidak diadakan untuk perubahan atau penyimpangan dari apa yang diharapkan (Moekijat, 1999). Menurut Peraturan Menteri Tenaga Kerja Nomor 3/MEN/1998 kecelakaan adalah suatu kejadian yang tidak dikehendaki dan tidak diduga semula yang dapat menimbulkan korban manusia dan harta benda (Sastrohadiwiryo, 2002). Menurut UU RI Nomor 3 Th. 1992 tentang Jaminan Sosial Tenaga Kerja, kecelakaan kerja adalah kecelakaan yang terjadi berhubungan dengan hubungan kerja, termasuk penyakit yang timbul akibat kerja, demikian pula kecelakaan yang terjadi dalam perjalanan berangkat dari rumah menuju ke tempat kerja dan pulang ke rumah melalui jalan yang biasa atau wajar dilalui (Wibowo, 2002).

Kecelakaan kerja dapat disebabkan oleh dua golongan penyebab (Endroyo, 1989), yaitu pertama, tindakan perbuatan manusia yang tidak memenuhi keselamatan (unsafe human acts) dan yang kedua keadaan-keadaan lingkungan yang tidak aman (unsafe condition). Walaupun manusia telah berhati-hati, namun apabila lingkungannya tidak menunjang (tidak aman), maka kecelakaan dapat pula terjadi. Begitu pula sebaliknya. Oleh karena itulah diperlukan pedoman bagaimana bekerja yang memenuhi prinsip-prinsip keselamatan.

\section{Keselamatan Kerja}

Menurut Bangun Wilson (2012:377) Keselamatan Kerja adalah perlindungan atas keamanan kerja yang dialami pekerja baik fisik maupun mental dalam lingkungan pekerjaan. Keselamatan kerja menunjukkan pada kondisi yang aman atau selamat dari penderitaan, kerusakan atau kerugian di tempat kerja. Adapun sasaran keselamatan kerja secara terinci adalah (Endroyo, 1989):

1. Mencegah terjadinya kecelakaan di tempat kerja

2. Mencegah timbulnya penyakit akibat kerja

3. Mencegah/mengurangi kematian akibat kerja

4. Mencegah atau mengurangi cacat tetap

5. Mengamankan material, konstruksi, pemakaian, pemeliharaan bangunan-bangunan, alat-alat kerja, mesin-mesin, pesawat-pesawat, instalasi-instalasi

6. Meningkatkan produktivitas kerja tanpa memeras tenaga kerja dan menjamin kehidupan produktifnya

7. Mencegah pemborosan tenaga kerja, modal, alat dan sumber-sumber produksi lainnya sewaktu kerja

8. Menjamin tempat kerja yang sehat, bersih, nyaman, dan aman sehingga dapat menimbulkan kegembiraan semangat kerja

9. Memperlancar, meningkatkan dan mengamankan produksi, industri serta pembangunan.

\section{Undang-Undang dan Peraturan Mengenai K3}

\section{Undang Undang No. 1/1970 Tentang Keselamatan Kerja}

UU No. 1 tahun 1970 tentang keselamatan kerja pasal 2 ayat 2 menyatakan bahwa syarat keselamatan kerja diberlakukan di tempat kerja, yaitu pembangunan, perbaikan, perawatan, pembersihan atau pembongkaran rumah, gedung atau bangunan lainnya termasuk bangunan pengairan, saluran atau terowongan di bawah tanah dan sebagainya atau di mana dilakukan pekerjaan persiapan

Dalam UU No. 1 tahun 1970 ini juga, pada pasal 9 angka 1 kewajiban pengurus K3 untuk menunjukan dan menjelaskan kepada tiap tenaga kerja baru tentang kondisikondisi dan bahaya-bahaya yang dapat timbul di tempat kerja.

\section{Peraturan Menteri Tenaga Kerja No. 01/1980 Tentang K3 Pada Konstruksi Bangunan}

Pada Bab I pasal 3 ayat 1,2,3, isinya antara lain; pada pekerjaan konstruksi diusahakan pencegahan kecelakaan atau sakit akibat kerja, disusun unit keselamatan dan 
Buletin Profesi Insinyur 1(1) (2018) 25-31

kesehatan kerja yang harus diberitahukan kepada setiap tenaga kerja, unit tersebut melakukan usaha pencegahan kecelakaan, kebakaran, peledakan, penyakit akibat kerja, P3K, dan usaha penyelamatan. Pasal 4 menyatakan bila terjadi kecelakaan kerja atau kejadian yang berbahaya harus dilaporkan kepada direktur atau pejabat yang ditujuk.

Pada Bab II pasal 5 mengharuskan di setiap tempat kerja dilengkapi dengan sarana untuk keluar masuk dengan aman; tempat, tangga, lorong, dan gang tempat orang bekerja atau sering dilalui harus dilengkapi dengan penerangan yang cukup semua tempat kerja harus mempunyai ventilasi yang cukup.

Surat Keputuan Bersama Menteri PU dan Menteri Tenaga Kerja No. 174/Men/1986-104/kpts/ 1986 Tentang K3 Pada Tempat Kegiatan Konstruksi

Pada bab I terdiri dari kewajiban umum kontraktor, organisasi keselamatan dan kesehatan kerja dan PPPK. Bab II tentang pintu masuk dan keluar, lampu penerangan, ventilasi, kebersihan, pencegahan terhadap kebakaran dan alat pemadam kebakaran, perlindungan terhadap bahanbahan jatuh dan bagian bangunan yang runtuh, perlindungan agar orang tidak jatuh. Bab III tentang perancah, yang diatur sangat rinci meliputi tempat bekerja, jalur pengangkut bahan, perancah dolken, perancah gantung, perancah dongkrak tangga, perancah siku dengan penunjang, perancah kuda-kuda, perancah pipa logam, perancah bergerak, perancah kursi gantung dan sebagainya.

\section{Peraturan No. 05/Menteri Tenaga Kerja/1996}

Sistem Manajemen Keselamatan dan Kesehatan Kerja adalah bagian dari sistem manajemen keseluruhan yang meliputi struktur organisasi, perencanaan, tanggung jawab, pelaksanaan, prosedur, proses dan sumber daya yang dibutuhkan bagi pengembangan, penerapan, pencapaian, pengkajian, dan pemeliharaan kebijakan keselamatan kerja dalam rangka pengendalian risiko yang berkaitan dengan kegiatan kerja guna terciptanya tempat kerja yang aman, efisien, dan produktif.

\section{UU No 18 Tahun 1999 Tentang Jasa Konstruksi}

Pasal 23 ayat 2 menyatakan bahwa penyeleng garaan pekejaan konstruksi wajib memenuhi ketentuan tentang keteknikan, keamanan, keselamatan dan kesehatan kerja, perlindungan tenaga kerja, serta tata lingkungan setempat untuk menjamin terwujudnya tertib penyelenggaraan pekerjaan konstruksi

\section{Undang-Undang No. 13/2003 Tentang Ketenaga kerjaan}

Pada pasal 86 menjelaskan bahwa setiap pekerja berhak untuk mendapatkan perlindungan atas keselamatan dan kesehatan kerja, moral dan kesusilaan dan perlakuan yang sesuai dengan harkat dan martabat manusia serta nilai-nilai agama. Pada pasal 87 menyatakan bahwa setiap perusahan wajib menerapkan sistem manajemen $\mathrm{K} 3$ yang terintregasi dengan sistem manajemen perusahaan.

\section{Peraturan Mengenai Sistem Manajemen K3}

Sistem Manajemen K3 adalah sistem yang digunakan untuk mengelola aspek K3 dalam organisasi atau perusahaan. Sistem manajemen K3 adalah pengelolaan K3 dengan menerapkan sistem manajemen untuk mencapai hasil yang efektif dalam mencegah kecelakaan dan efek lain yang merugikan.

Berdasarkan definisi tersebut maka Sistem Manajemen K3 juga terjadi atas komponen-komponen yang saling terkait dan terintegrasi satu dengan lainnya. Komponenkomponen ini sering disebut elemen sistem manajemen K3 (Ramli, 2013).

\section{Peraturan Menteri PU No. 9 Tahun 2008}

Sistem Manajemen Keselamatan dan Kesehatan Kerja (SMK3) adalah bagian dari sistem manajemen secara keseluruhan yang meliputi struktur organisasi, perencanaan, tanggung jawab, pelaksanaan, prosedur, proses dan sumber daya yang dibutuhkan bagi pengembangan penerapan, pencapaian, pengkajian dan pemeliharaan kebijakan keselamatan dan kesehatan kerja guna terciptanya tempat kerja yang selamat, aman, efisien dan produktif.

SMK3 konstruksi bidang pekerjaan umum adalah SMK3 pada sektor jasa konstruksi yang berhubungan dengan kepentingan umum (masyarakat) antara lain pekerjaan konstruksi: jalan, jembatan, bangunan gedung fasilitas umum, sistem penyediaan air minum dan perpipaannya, sistem pengolahan air limbah dan perpipaannya, drainase, pengolahan sampah, pengaman pantai, irigasi, bendungan, bendung, waduk, dan lainnya.

Pada bab 3 peraturan menteri PU nomor 9 tahun 2008 pasal 4 dijelaskan tentang ketentuan penyelenggaraan sistem manajemen keselamatan dan kesehatan kerja di bidang konstruksi, adapun ketentuannya sebagai berikut:

1. Kegiatan jasa konstruksi yang dilaksanakan oleh pengguna jasa/penyedia jasa terdiri dari jasa pemborongan, jasa konsultasi dan kegiatan swakelola yang aktifitasnya melibatkan tenaga kerja dan peralatan kerja untuk keperluan pelaksa naan pekerjaan fisik di lapangan wajib menyeleng garakan SMK 3 konstruksi bidang pekerjaan umum.

2. Penyelenggaraan SMK3 Konstruksi Bidang Pekerjaan Umum wajib menggunakan pedoman ini beserta lampirannya

3. Penyelenggaraan SMK3 Konstruksi Bidang Pekerjaan Umum dikelompokkan menjadi tiga kategori, yaitu:

Risiko Tinggi, adalah mencakup pekerjaan konstruksi yang pelaksanaannya berisiko sangat membahayakan keselamatan umum, harta benda, jiwa manusia dan lingkungan serta terganggunya kegiatan konstruksi Risiko Sedang, adalah mencakup pekerjaan konstruksi yang pelaksanaannya dapat berisiko membahayakan keselamatan umum, harta benda dan jiwa manusia serta terganggunya kegiatan konstruksi

Risiko Kecil, adalah mencakup pekerjaan konstruksi yang pelaksanaannya tidak membahayakan keselamatan umum dan harta benda serta terganggunya kegiatan konstruksi

4. Kinerja penerapan penyelenggaraan SMK3 Konstruksi Bidang Pekerjaan Umum dibagi mencapai tiga, yaitu: Baik, bila mencapai hasil penilaian $>85 \%$; 
Buletin Profesi Insinyur 1(1) (2018) 25-31

Sedang, bila mencapai hasil penilaian $60 \%-85 \%$;

Kurang, bila mencapai hasil penilaian $<60 \%$.

5. Dalam rangka penyelenggaraan SMK3 Konstruksi Bidang Pekerjaan

Umum harus dibuat Rencana Keselamatan dan Kesehatan Kerja Kontrak (RK3K) oleh penyedia jasa dan disetujui oleh pengguna jasa.

6. Di tempat kerja harus selalu terdapat pekerja yang sudah terlatih dan/atau bertanggung jawab dalam Pertolongan Pertama Pada Kecelakaan (P3K)

7. Untuk kegiatan swakelola, perlu ada penentuan tentang:

Pihak yang berperan sebagai penyelenggara langsung Pihak yang berperan sebagai pengendali.

\section{Peraturan Pemerintah (PP) No. 50 Tahun 2012}

SMK3 adalah bagian dari sistem manajemen perusahaan secara keseluruhan dalam rangka pengendalian risiko yang berkaitan dengan kegiatan kerja guna terciptanya tempat kerja yang aman, efisien, dan produktif.

Mengapa perlu adanya SMK3? Sistem manajemen diperlukan untuk meningkatkan upaya K3 yang dijalankan dalam perusahaan agar berjalan secara efisien dan efektif.

\section{Fasilitas Keselamatan dan Kesehatan Kerja}

Untuk menjamin Keselamatan dan Kesehatan Kerja dapat berlangsung dengan baik perlu diperhatikan fasilitasfasilitas standar yang mendukung kegiatan dapat berjalan dengan aman. APD standar seperti helm proyek, sepatu pelindung, pelindung mata, masker dan pelindung telinga. Selain pakaian pelindung tersebut, pemasangan papanpapan peringatan, rambu lalu lintas, ketentuan atau peraturan pengunaan peralatan yang sesuai dengan fungsinya dan ketentuan-ketentuan yang membuat lokasi kegiatan aman dan di dukung oleh personil yang menangan setiap kegiatan menguasai operasional akan menjamin keselamatan dan kesehatan kerja dapat berlangsung baik. Fasilitas pendukung Keselamatan dan Kesehatan Kerja merupakan hal yang pokok selain perencanaan, pelatihan, dan pengawasan. Fasilitas yang dimaksud disini meliputi fasilitas yang berada di sekitar proyek dan yang melekat pada diri pekerja.

\section{Macam-Macam APD}

Alat-alat pelindung diri yang standar pada proyek konstruksi ada berbagai macam, antara lain:

Helm proyek, helm sangat penting digunakan sebagai pelindung kepala, dan sudah merupakan keharusan bagi setiap pekerja konstruksi untuk menggunakannya dengan benar sesuai peraturan

Masker, berbagai material konstruksi berukuran besar sampai sangat kecil yang merupakan sisa dari suatu kegiatan, misalnya serbuk kayu dapat mengganggu pernafasan maka dari itu perlu digunakan masker

Pakaian kerja, digunakan untuk melindungi badan manusia terhadap pengaruh-pengaruh yang kurang sehat atau yang bias melukai badan

Sarung tangan, digunakan untuk melindungi tangan dari benda-benda keras dan tajam selama menjalankan kegiatan

Sepatu, setiap pekerja konstruksi perlu memakai sepatu dengan sol yang tebal supaya bisa bisa bebas berjalan kemana-mana tanpa terluka oleh benda tajam.

\section{Macam-Macam Fasilitas Pengaman Proyek}

Selain adanya APD maka perlu juga dilengkapi oleh alat pengaman pada proyek konstruksi yang gunanya untuk menunjang keamanan pada proyek tersebut. Macammacam fasilitas pengaman proyek, antara lain:

Jaring pengaman, digunakan untuk mencegah adanya benda atau material proyek yang jatuh kebawah

Rambu-rambu, dipasang untuk menginformasikan sesuatu yang ada di dalam proyek dan sebagi tanda bahaya.

Hydrant, digunakan untuk pertolongan pertama jika terjadi kebakaran pada proyek

Spanduk peringatan K3, adanya spanduk ataupun poster di proyek agar seluruh pekerja proyek paham mengenai K3 dan pencegahan kecelakaan kerja

Alarm peringatan, digunakan untuk mengumum kan kepada semua orang yang berada di proyek jika terjadi suatu bahaya

Lampu peringatan, digunakan sebagai tanda bahaya di dalam maupun di luar proyek.

\section{Jenis-jenis Penerapan SMK3}

Penerapan SMK3 dalam organisasi bertujuan untuk meningkatkan kinerja K3 dengan melaksanakan upaya K3 secara efisien dan efektif sehingga risiko kecelakaan dan penyakit akibat kerja dapat dicegah atau dikurangi. Setiap organisasi memiliki risiko K3 sesuai dengan sifat dan jenis kegiatannya. Karena itu organisasi tersebut pasti sudah menjalankan upaya $\mathrm{K} 3$, yang membedakan adalah kualitas implemen tasinya.

Dalam organisasi yang tradisional, program K3 mungkin telah dilakukan namun tidak menggunakan kerangka sistem yang baik. Bentuknya tidak beraturan dan acak, sehingga hasil yang dicapai juga kurang efektif.

Sering perusahaan telah menerapkan SMK3, tetapi kecelakaan masih saja terjadi. Hal tersebut disebabkan karena kualitas penerapan SMK3 di dalam perusahaan masih belum menyeluruh dan lengkap (komprehensif). Beberapa jenis penerapan SMK3 adalah sebagai berikut :

SMK3 Virtual: Organisasi telah memiliki elemen SMK3 dan melakukan langkah pencegahan yang baik, namun tidak memiliki sistem yang mencerminkan bagaimana langkah pengamanan dan pengendalian risiko dijalankan.

SMK3 Salah Arah: Organisasi telah memiliki elemen SMK3 yang baik, tetapi salah arah dalam mengembangkan langkah pencegahan dan pengamanannya. Akibatnya isu atau potensi bahaya yang bersifat kritis bagi organisasi terlewatkan.

SMK3 Acak: Organisasi yang telah menjalankan program pengendalian dan pencegahan risiko yang tepat sesuai dengan realita yang ada dalam organisasi, namun tidak memiliki elemen-elemen manajemen $\mathrm{K} 3$ yang diperlukan untuk memastikan bahwa proses pencegahan dan pengendalian tersebut berjalan dengan baik. Elemen K3 yang digunakan bersifat acak dan tidak memiliki keterkaitan satu dengan lainnya. 
Buletin Profesi Insinyur 1(1) (2018) 25-31

SMK3 Komprehensif: Organisasi yang menerapkan dan mengikuti proses sistem yang baik. Elemen SMK3 dikembangkan berdasarkan hasil identifikasi risiko, dilanjutkan dengan menetapkan langkah pencegahan dan pengamanan, serta melalui proses manajemen untuk menjamin penerapannya secara baik (Ramli, 2010).

Penulisan ini dilakukan berdasarkan pada hasil penilaian dan monitoring serta evaluasi komponen utama penyelenggaraan SMK3, yaitu meliputi:

\section{Penilaian Kinerja Penerapan Penyelenggaraan SMK3 Untuk mengetahui Kinerja Penerapan} Penyelenggaraan SMK3 Proyek Peningkatan Struktur Jalan Batas Kota Muara Tewe Kandui, dilakukan Monitoring dan Evaluasi SMK3 Konstruksi (Monev SMK3). Maksud Penyelenggaraan Monev SMK3 adalah untuk mengukur tingkat penyelenggaraan SMK3 dalam pemenuhan syaratsyarat keamanan, keselamatan dan kesehatan kerja pada tempat kegiatan konstruksi dan bertujuan untuk pembinaan penerapan SMK3 Konstruksi di lingkungan Kementerian PU. Monev dilakukan kepada pihak pengguna jasa, yaitu Satker dan PPK serta pihak penyedia jasa.

\section{Monev Pengguna Jasa (Satker):}

1. Satker menerapkan SMK3 Konstruksi Bidang PU secara penuh mengacu pada Permen PU No. 09/PRT/M/2008 tentang Pedoman Sistem Manajemen Keselamatan Dan Kesehatan Kerja (K3) Konstruksi Bidang Pekerjaan Umum

2. Persyaratan K3 dimasukkan dalam Dokumen Pemilihan Penyedia Jasa oleh Pokja Satker

3. Satker sudah mempunyai dan memasang Kebijakan K3 dan Pakta Komitmen K3 Kementerian PU, dipasang di tempat yang mudah dibaca dan disosialisasikan kepada unit kerja/staf di bawah kendali Satker

4. Satker mempunyai Prosedur Teknis tentang Pelaksanaan SMK3 Konstruksi yang diterbitkan oleh Pejabat Eselon I, sesuai Permen PU No. 09/PRT/M/2008 Pasal 7 ayat (1)

5. Satker mempunyai Petunjuk Teknis Pelaksanaan Monitoring dan Evaluasi Penyelenggaraan SMK3 Konstruksi

\section{Monev Pengguna Jasa (PPK) :}

1. Kebijakan K3 dan Pakta Komitmen K3 Kementerian PU terpasang di Kantor dan disosialisasikan kepada seluruh pejabat dan staf

2. PPK telah menugaskan Penyedia Jasa untuk menyelenggarakan SMK3 Konstruksi sesuai RK3K dan meminta Penyedia Jasa untuk mengkaji ulang RK3K pada bagian yang perlu dikaji ulang

3. PPK sudah menjelaskan tentang risiko K3 Konstruksi pada saat aanwijzing, termasuk kondisi dan bahaya yang dapat timbul dalam pelaksanaan pekerjaan

4. PPK melibatkan Petugas K3/Ahli K3 Konstruksi dalam menentukan kategori risiko seluruh paket kegiatan yang dikendalikannya
5. PPK dan Penyedia Jasa menetapkan tingkat risiko dan dilakukan pembahasan tingkat risiko K3. Dalam menetapkan tingkat risiko K3, PPK berkonsultasi dengan Ahli K3 Konstruksi

6. PPK memahami dan menerapkan SMK3 dan wewenangnya dalam penyelenggaraan SMK3 Konstruksi sesuai tugas, tanggung jawab dan wewenangnya mengacu pada Permen PU No. 09/PRT/M/2008, pasal 10 tentang Tugas, Tanggung Jawab dan Wewenang Pejabat Pembuat Komitmen (PPK)

Monev Penyedia Jasa :

1. Kebijakan K3 Penyedia Jasa berdasarkan kebijakan KSO PP-GNG-BLJ dan disepakati bersama

2. Sasaran dan Program kerja telah dibuat secara rinci dan terukur

3. Penyedia Jasa melengkapi daftar Permen PU Nomor 09/PRT/M/2008 tentang Pedoman Sistem Manajemen Keselamatan Dan Kesehatan Kerja (K3) Konstruksi Bidang Pekerjaan Umum sebagai acuan dalam pelaksanakan SMK3 Bidang Pekerjaan Umum

4. Penyedia Jasa melengkapi Surat Keputusan Bersama Menteri Tenaga Kerja dan Menteri Pekerjaan Umum No. 174/MEN/1986 dan 104/KPTS/1986 tentang K3 Pada Tempat Kegiatan Konstruksi

5. Penyedia Jasa melengkapi Pedoman Pelaksanaan K3 untuk Konstruksi Jalan dan Jembatan No. 004/BM/2006

6. Komunikasi informasi mengenai standar dan persyaratan teknis pelaksanaan akibat adanya perubahan yang dilakukan kepada seluruh pekerja termasuk kepada Subkontraktor

7. RK3 Kontrak dijadikan sebagai bagian yang tidak terpisahkan dari Dokumen Kontrak, karena RK3K yang pada saat monev sudah divalidasi merupakan sarana interaksi Pengguna Jasa dan Penyedia Jasa dalam penyelenggaraan $\mathrm{K} 3$ proyek.

8. Penyedia Jasa sudah membentuk Struktur Organisasi P2K3 (Panitia Pembina K3)

9. Penyedia Jasa melaksanakan audit internal K3 secara berkala sesuai dengan Permen PU No 09 / PRT / M / 2008 dan dilaksanakan per 6 (enam) bulan.

10. Penyedia Jasa melakukan pelatihan K3 dan evaluasi efektifitas pelatihan didokumentasikan.

11. Dalam melaporkan kecelakaan kerja ditembuskan kepada PPK dan Ka. Satker (Pengguna Jasa), karena Pengguna Jasa sesuai dengan Permen 09/2008 ikut bertanggung jawab terhadap kecelakaan kerja yang terjadi.

12. Penyedia Jasa membuat laporan tentang kecelakaan kerja ke Disnaker setempat secara berkala 3 bulanan (ada kecelakaan maupun tidak ada kecelakaan).

\section{Hasil dan Pembahasan}

Hasil monev dan penilaian Kinerja Penerapan Penyelenggaraan SMK3 dari proyek ditunjukkan sebagaimana dalam Tabel 1 berikut: 
Buletin Profesi Insinyur 1(1) (2018) 25-31

Tabel 1. Hasil Penilaian Kinerja Penerapan Penyelenggaraan SMK3

\begin{tabular}{|c|c|c|c|c|}
\hline \multirow{2}{*}{ No } & \multirow{2}{*}{ Indikator } & \multicolumn{3}{|c|}{ Nilai } \\
\hline & & Bobot & Sub Total & Total \\
\hline 1 & Kebijakan K3 Perusahaan Penyedia Jasa & $7 \%$ & 92 & 6,44 \\
\hline 2 & Perencanaan & & & \\
\hline 2.1 & Identifikasi Bahaya, Penilaian Risiko dan Pengendaliannya & $10 \%$ & 85 & 8,5 \\
\hline 2.2 & Pemenuhan Perundang-Undangan dan Persyaratan Lainnya & $5 \%$ & 88,50 & 4,275 \\
\hline 2.3 & Sasaran dan Program & $6 \%$ & 85 & 5,1 \\
\hline 3 & Penerapan dan Operasi & & & \\
\hline 3.1 & Sumber Daya, Struktur Organisasi dan Pertanggungjawaban & $5 \%$ & 100 & 5 \\
\hline 3.2 & Kompetensi, Pelatihan dan Kepeduliani & $5 \%$ & 88 & 4,4 \\
\hline 3.3 & Komunikasi, Partisipasi dan Konsultasi & $5 \%$ & 95 & 4,75 \\
\hline 3.4 & Dokumentasi & $5 \%$ & 80 & 4 \\
\hline 3.5 & Pengendalian Dokumen & $7 \%$ & 82 & 5,74 \\
\hline 3.6 & Pengendalian Operasional & $7 \%$ & 80 & 5,6 \\
\hline 3.7 & Kesiagaan dan Tanggap Darurat & $7 \%$ & 82 & 5,74 \\
\hline 4 & Pemeriksaan & & & \\
\hline 4.1 & Pengukuran dan Pemantauan & $6 \%$ & 82,5 & 4,95 \\
\hline 4.2 & Evaluasi Kepatuhan & $5 \%$ & 96 & 4,8 \\
\hline 4.3 & $\begin{array}{l}\text { Penyelidikan Insiden, Ketidaksesuaian, Tindakan Perbaikan dan } \\
\text { Pencegahan }\end{array}$ & $6 \%$ & 90 & 5,4 \\
\hline 4.4 & Pengendalian Rekaman & $5 \%$ & 80 & 4 \\
\hline 4.5 & Audit Internal & $5 \%$ & 84 & 4,2 \\
\hline \multirow{2}{*}{5} & Tinjauan Manajemen & $6 \%$ & 90 & 5,4 \\
\hline & Total & $100 \%$ & & 88,295 \\
\hline
\end{tabular}

Dari tabel 1 didapatkan bahwa kinerja penerapan penyelenggaraan SMK3 Proyek Pembangunan Jalan Akses Menuju Pelabuhan Trisakti-Liang Anggang termasuk dalam kondisi Baik (hasil penilaian > 85).

\section{Hasil Penilaian Kelengkapan Fasilitas K3}

Sementara itu hasil penilaian Kelengkapan Fasilitas K3 dapat ditunjukkan sebagaimana dalam Tabel 2 berikut:

Tabel 2. Hasil Penilaian Kelengkapan Fasilitas K3

\begin{tabular}{|c|c|c|c|c|c|c|c|}
\hline \multirow{2}{*}{ No } & \multirow{2}{*}{ Indikator yang dinilai } & \multicolumn{5}{|c|}{ Skor } & \multirow{2}{*}{ Total } \\
\hline & & 1 & 2 & 3 & 4 & 5 & \\
\hline \multirow[t]{6}{*}{1} & Alat Pelindung Diri & & & & & & \\
\hline & Helm & & & & & $\sqrt{ }$ & 5 \\
\hline & Sepatu & & & & & $\sqrt{ }$ & 5 \\
\hline & Sarung tangan & & & $\sqrt{ }$ & & & 3 \\
\hline & Rompi & & & & $\sqrt{ }$ & & 4 \\
\hline & Masker & & & $\sqrt{ }$ & & & 3 \\
\hline \multirow[t]{8}{*}{2} & Fasilitas pengaman proyek & & & & & & \\
\hline & Jaring pengaman & & $\sqrt{ }$ & & & & 2 \\
\hline & Rambu-rambu & & & V & & & 3 \\
\hline & Hydrant & & & & & $\sqrt{ }$ & 5 \\
\hline & Spanduk peringatan $\mathrm{K} 3$ & & & & & V & 5 \\
\hline & Alarm peringatan & & & & & V & 5 \\
\hline & Lampu peringatan & & & & & $\sqrt{ }$ & 5 \\
\hline & Jumlah & 0 & 2 & 9 & 4 & 30 & 45 \\
\hline \multicolumn{2}{|c|}{ Persentase = Jumlah / Jumlah Skor ideal x 100\% } & 0 & 3,6 & 16,4 & 7,3 & 54,55 & 81,2 \\
\hline \multicolumn{8}{|c|}{ Keterangan: } \\
\hline 1 & : tidak tersedia & & $=0 \%$ & & & & \\
\hline 2 & : tersedia, tidak layak dan tidak lengkap & & $=3,6 \%$ & & & & \\
\hline 3 & : tersedia, layak, tidak lengkap & & $=16,4 \%$ & & & & \\
\hline 4 & : tersedia, tidak layak, lengkap & & $=7,3 \%$ & & & & \\
\hline 5 & : tersedia, layak, lengkap & & $=54,55 \%$ & & & & \\
\hline
\end{tabular}


Kelima skor tersebut dinilai berdasarkan ketersediaan kelengkapan fasilitas K3 pada proyek. Skor dinyatakan tidak layak jika item yang dimaksud mengalami kerusakan, skor dinyatakan tidak lengkap jika item tersebut jumlahnya tidak memenuhi jumlah pekerja di proyek terkait. Tabel 2 menunjukkan kelengkapan fasilitas $\mathrm{K} 3$ yang tersedia pada proyek memiliki nilai sebesar $81,2 \%$. Nilai ini dikategorikan Sedang.

\section{Kesimpulan}

Sesuai dengan tujuan penelitian, maka kesimpulan dari analisis dan pembahasan adalah sebagai berikut:

1. Pelaksanaan SMK3 pada Proyek Pembangunan Jalan Akses Menuju Pelabuhan Trisakti-Liang Anggang dalam kondisi yang sangat baik. Hal tersebut diwujudkan dalam bentuk kinerja penerapan penyelenggaraan SMK3 berdasarkan Peraturan Menteri PU No. 9 tahun 2008 dengan nilai 88,295\%.

2. Kelengkapan fasilitas yang berkaitan dengan pelaksanaan sistem SMK3 pada Proyek Pembangunan Jalan Akses Menuju Pelabuhan Trisakti-Liang Anggang dikategorikan sedang, yang ditunjukkan dari hasil Penilaian Kelengkapan Fasilitas K3 berdasarkan Peraturan Menteri PU No. 9 tahun 2008 dengan nilai $81,2 \%$.

\section{Daftar Pustaka}

Endroyo, B. 1989. Keselamatan Kerja Untuk Teknik Bangunan. IKIP Semarang Press. Semarang.

Kementrian Pekerjaan Umum. 2011. Kebijakan Pemerintah Tentang K3. Permen PU No: 09/PRT/M/2008. 1 Jul 2008. Jakarta.

Bangun, W. 2012. Manjemen Sumber Daya Manusia. Erlangga, Jakarta.

Pangkey, F., G.Y. Malingkas dan DOR. Walangitan. 2012. Penerapan Sistem Manajemen Keselamatan dan Kesehatan Kerja (SMK3) Pada Proyek Konstruksi di Indonesia (Studi Kasus: Pembangunan Jembatan Dr. Ir. Soekarno-Manado). Jurnal Ilmiah MEDIA ENGINEERING. 2(2): 100-113.

Pemerintah Republik Indonesia. 1997. Dasar-dasar K3 Konstruksi. Menteri Tenaga Kerja PERMEN Nomor: PER-05/MEN/1999. Jakarta.

Peraturan Menteri Pekerjaan Umum No. 9 Tahun 2008

Peraturan Pemerintah No. 5 Tahun 2012

Ridley J. 2004. Kesehatan dan Keselamatan Kerja, Penerbit Erlangga, Jakarta.

Armanda D. 2006. Penerapan SMK3 Bidang Konstruksi Medan, Jakarta.

Ramli, S. 2010. Sistem Manajemen Keselamatan dan Kesehatan Kerja OHSAS 18001. PT. Dian Rakyat. Jakarta.

Ramli, S. 2013. Smart Safety Panduan Penerapan SMK3 yang efektif. Dian Rakyat. Jakarta.

Teja, M.B.S. 2015. Pengaruh Pengetahuan Keselamatan Dan Kesehatan Kerja Terhadap Perilaku Pekerja Konstruksi Pada Proyek Jalan Tol Nusa Dua-Ngurah Rai-Benoa. Program Pascasarjana. Universitas Udayana. Denpasar.

Moekijat. 1999. Manajemen Sumber Daya Manusia (Manajemen Kepegawaian), Mandar Maju, Bandung.
Sastrohadiwiryo, S. B. 2002. Manajemen Tenaga Kerja Indonesia (Pendekatan Administratif dan Operasional), PT. Bumi Aksara, Jakarta.

Sholihah, Q. 2012. Dasar-Dasar Kesehatan dan Keselamatan Kerja (Penerapan dan Implementasi). Jakarta: AVICENA Pustaka.

Sholihah, Q. 2013. Keselamatan dan Kesehatan Kerja, Konsep, Perkembangan dan Implementasi Budaya Keselamatan. Jakarta: Penerbit Buku Kedokteran EGC.

Wibowo, M. B. S. 2002. Himpunan Perundangan Ketenagakerjaan, Andi Yogyakarta, Yogyakarta. 